\title{
The San Francisco Volcanic Field, Arizona
}

orthern Arizona's San Francisco Volcanic Field, much of which lies within Coconino and Kaibab National Forests, is an area of young volcanoes along the southem margin of the Colorado Plateau. During its 6million-year history, this field has produced more than 600 volcanoes. Their activity has created a topographically varied landscape with forests that extend from the Piñon-Juniper up to the Bristlecone Pine life zones. The most prominent landmark is San Francisco Mountain, a stratovolcano that rises to 12,633 feet and serves as a scenic backdrop to the city of Flagstaff.

The San Francisco Volcanic Field, which covers about 1,800 square miles, is part of northern Arizona's spectacular landscape. Much of the field lies within Coconino and Kaibab National Forests. Forest life zones in the region range from Piñon-Juniper at lower elevations through Ponderosa Pine to Fir and Bristlecone Pine at the highest elevations. The varied forests and geologic features of the San Francisco Volcanic Field offer diverse recreational opportunities, including camping, hiking, mountain biking, wildlife viewing, and winter sports.

Almost all hills and mountains between Flagstaff and the Grand Canyon are geologically young but extinct volcanoes of the San Francisco Volcanic Field. Without the volcanoes, this region would be a flat, arid plateau. Instead, the area includes both Arizona's highest mountain-San Francisco Mountain, with peaks rising to 12,633 feet-and the State's youngest volcano-Sunset Crater, which erupted less than 1,000 years ago and has been a National Monument since 1930.

Why does Northern Arizona have so many geologically young volcanoes? Most volcanoes are located near boundaries of the Earth's tectonic plates, but Arizona is well within the

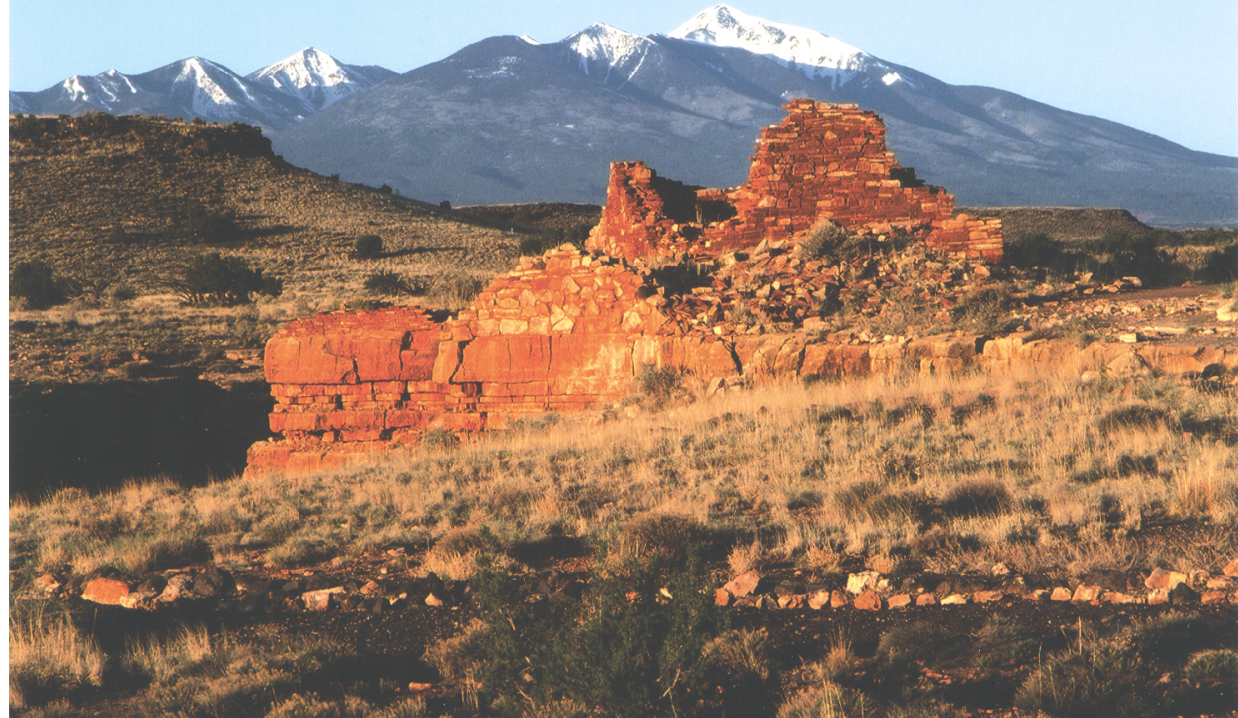

The peaks of San Francisco Mountain, an eroded stratovolcano—which includes Arizona's highest point, Humphreys Peak at 12,633 feet-tower over the ruins of an ancient Native American pueblo in Wupatki National Monument. The ancient inhabitants of this area must have witnessed the eruption of nearby Sunset Crater, the State's youngest volcano, which erupted in about A.D. 1064. San Francisco Mountain and Sunset Crater are only two of the hundreds of volcanoes in the San Francisco Volcanic Field, which covers about 1,800 square miles of northern Arizona. (Copyrighted photo courtesy of Michael Collier.)

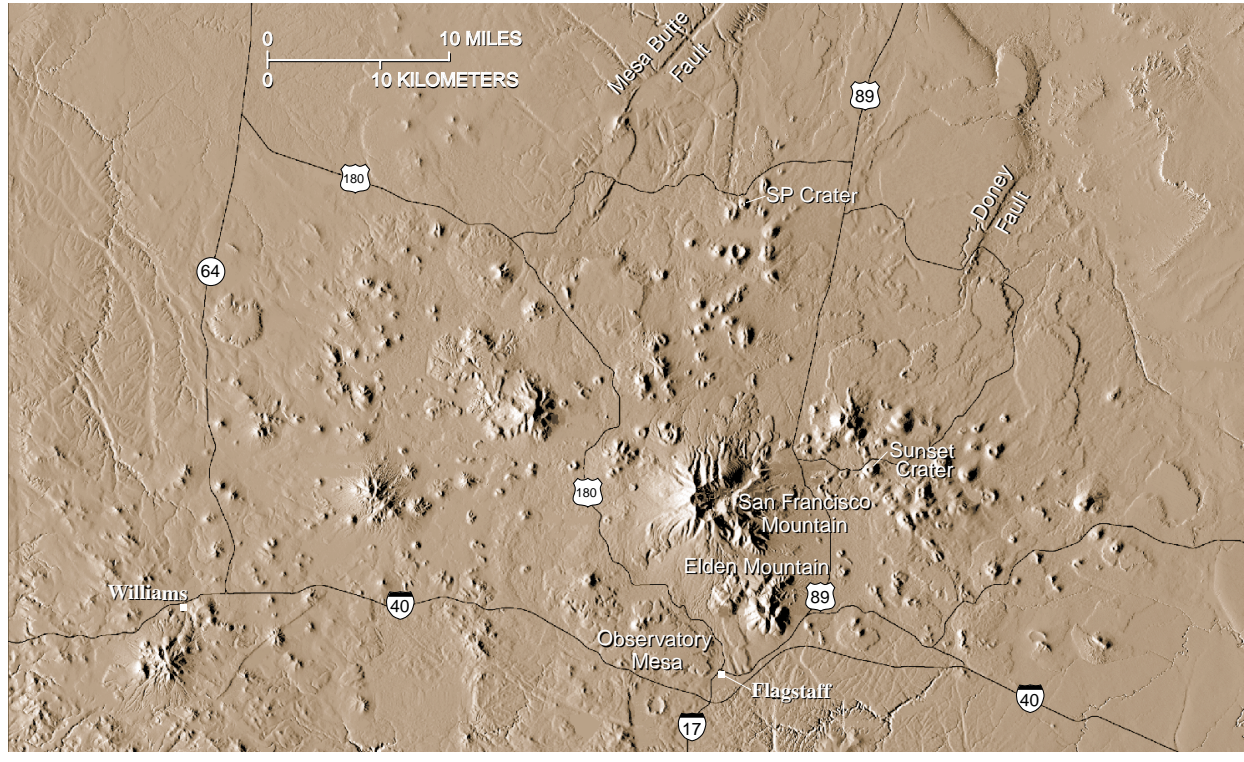

This digital elevation model (DEM) of the San Francisco Volcanic Field shows many of the more than 600 vents which have erupted in the area during the past 6 million years. Some lava flows (flat lobate features) are easily recognized by their proximity to vents. Larger tectonic structures such as the northeast-trending Mesa Butte Fault and Doney Fault are also seen. Flagstaff lies at the south-central edge of the volcanic field nestled between the base of Elden Mountain and the Observatory Mesa flow emitted from A-1 Mountain. 
interior of the North American Plate. Some geologists suggest that there is a site of localized melting, or "hot spot," fixed deep within the Earth's mantle beneath northern Arizona. As the North American Plate moves slowly westward over this stationary source of molten rock (magma), eruptions produce volcanoes that are strung out progressively eastward.

The first volcanoes in the San Francisco Volcanic Field began to erupt about 6 million years ago, in an area where the town of Williams is now. Subsequently, a several-mile-wide belt of successively younger eruptions migrated eastward, to the area of modern Flagstaff, and even a bit beyond, toward the valley of the Little Colorado River. Today, this belt of volcanoes extends about 50 miles from west to east.

Although there has been no eruption for nearly 1,000 years, it is likely that eruptions will occur again in the San Francisco Volcanic Field. With an average interval of several thousand years between past periods of volcanic activity, it is impossible to forecast when the next eruption will occur. U.S. Geological Survey (USGS) scientists believe that the most probable sites of future eruptions are in the eastern part of the field and that the eruptions are likely to be small. These future eruptions may provide spectacular volcanic displays but should pose little hazard because of their small size and the relative remoteness of the area.

\section{Volcanoes and Types of Magma}

A volcano is an opening where magma erupts onto the surface as lava after rising from deep within the Earth. Not all magma is the same. Some magma contains as much as $75 \%$ silica $\left(\mathrm{SiO}_{2}\right)$, whereas other magma contains as little as about 50\%. The more silica in a magma, the higher its viscosity, or resistance to flow. Viscosity controls the type of volcano that forms.

Eruptions of high-viscosity magma build very steep-sided lava domes. Low-viscosity magma produces cinder cones and thin sheet-like lava

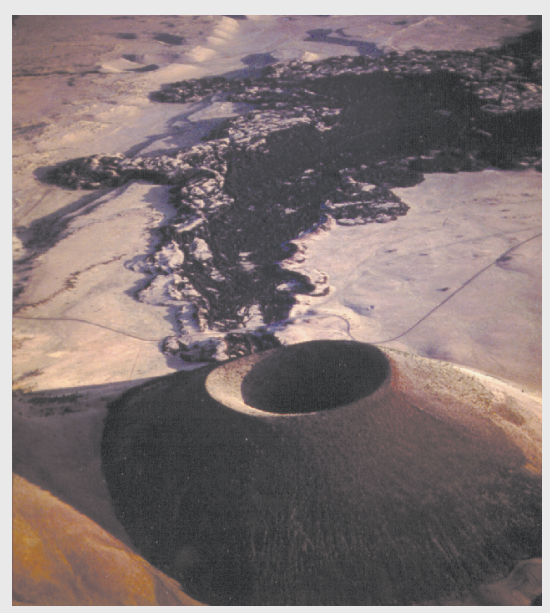

SP Crater, in the San Francisco Volcanic Field, is an excellent example of a cinder cone and associated lava flow. This flow extends 4 miles from the cone and is only about 100 feet thick. flows, and intermediate-viscosity magma creates moderately steep mountains called stratovolcanoes.

Most of the more than 600 volcanoes in the San Francisco Volcanic Field are basalt cinder cones. Basalt has the lowest viscosity of all common magmas. Cinder cones are relatively small, usually less than 1,000 feet tall, and form within months to years. They are built when gas-charged frothy blobs of basalt magma are erupted as an upward spray, or lava fountain. During flight, these lava blobs cool and fall back to the ground as dark volcanic rock containing cavities created by trapped gas bubbles. If small, these fragments of rock are called "cinders" and, if larger, "bombs." As the fragments accumulate, they build a cone-shaped hill. Once sufficient gas pressure has been released from the supply of magma, lava oozes quietly out to form a lava flow. This lava typically squeezes out from the base of the cone and tends to flow away for a substantial distance because of its low viscosity. SP Crater, 25 miles north of Flagstaff, is an excellent example of a cinder cone and its associated lava flow.

\section{Stratovolcanoes}

Stratovolcanoes have moderately steep slopes and form by the accumulation of layer upon layer of intermediate-viscosity (andesite) lava flows, cinders, and ash, interspersed with deposits from volcanic mudflows (lahars) at lower elevations. These tall, cone-shaped volcanoes, such as Mount Rainier, Washington, and Mount Fuji, Japan, normally rise to a central peak and are built up by countless eruptions over hundreds of thousands of years.

San Francisco Mountain is the only stratovolcano in the San Francisco Volcanic Field and was built by eruptions between about 1 and 0.4 million years ago. Since then, much of the mountain has been removed to create the "Inner Basin." The missing material may have been removed quickly and explosively by an eruption similar to the 1980 eruption of Mount St. Helens, Washington, or it may have been removed slowly and incrementally by a combination of large landslides, water erosion, and glacial scouring.

\section{Lava Domes}

The San Francisco Volcanic Field also includes several lava domes. Lava domes are formed by dacite and rhyolite magmas, which have high silica contents. Dacite and rhyolite are so viscous that they tend to pile up and form very steep-sided bulbous masses (domes) at the site of eruption. Domes can be active for decades or sometimes centuries. If a lava dome grows entirely by internal inflation, similar to a balloon, it is called an endogenous dome. If, however, magma breaks out through a dome's flank during inflation and adds new lava layers to the outer surface, the final dome is called exogenous.

Elden Mountain, at the eastern outskirts of Flagstaff, is an excellent example of an exogenous dacite dome and consists of several overlapping lobes of lava. Sugarloaf Mountain, at the entrance

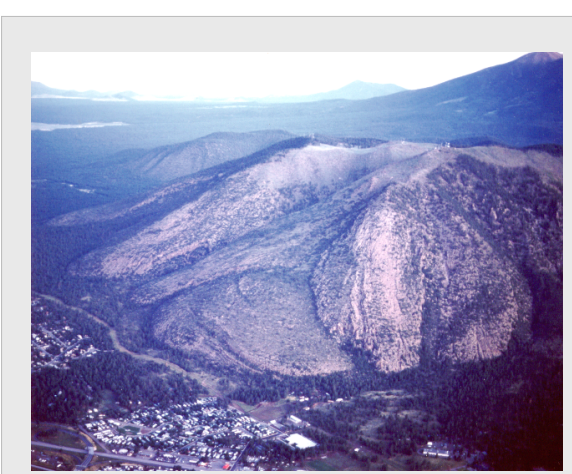

Elden Mountain is a steep-sided lava dome in the San Francisco Volcanic Field. Lava domes are formed by dacite and rhyolite magmas, which have high silica contents. Dacite and rhyolite are so viscous that they tend to pile up and form very steep-sided bulbous masses (domes) at the site of eruption.

to San Francisco Mountain's Inner Basin, is a rhyolite lava dome. This dome is thought to be endogenous, but its forest cover hides direct evidence of its internal structure.

The work of USGS scientists, in cooperation with the U.S. Forest Service, has led to a better understanding of the history of volcanism in the San Francisco Volcanic Field. This work is only part of the USGS Volcano Hazards Program's ongoing efforts to protect people's lives and property in all of the volcanic regions of the United States, including the Pacific Northwest, eastern California, Wyoming, Alaska, and Hawaii.

Susan S. Priest, Wendell A. Duffield, Karen Malis-Clark, James W. Hendley II, and Peter H. Stauffer

Graphic design by

Stephen L. Scott

Banner design by Bobbie Myers

\section{COOPERATING ORGANIZATIONS}

Bureau of Land Management National Park Service

U.S. Department of Agriculture, Forest Service

$$
\begin{gathered}
\text { For more information contact: } \\
\text { U.S. Geological Survey } \\
2255 \text { N Gemini Dr. } \\
\text { Flagstaff, AZ } 86001 \\
\text { (520) 556-7148 } \\
\text { http://volcanoes.usgs.gov/ } \\
\text { or } \\
\text { U.S. Forest Service } \\
\text { Coconino National Forest, } \\
\text { Peaks Ranger District } \\
\text { 5075 N. Highway } 89 \\
\text { Flagstaff, AZ } 86004 \\
\text { (520) 526-0866 } \\
\text { http://www.fs.fed.us/r3/coconino/ }
\end{gathered}
$$

See also What are Volcano Hazards? (USGS Fact Sheet 002-97), Volcanoes (USGS General Interest Publication 94-0195), and Volcanoes of Northern Arizona by Wendell Duffield (Grand Canyon Association, 1997)

This Fact Sheet and any updates to it are available on line at http://geopubs.wr.usgs.gov/fact-sheet/fs017-01 